\title{
Texture, mineralogy and geochemistry of Teri sediments from the Kuthiraimozhi deposit, Southern Tamilnadu, India: implications on provenance, weathering and palaeoclimate
}

\author{
Udayanapillai Alagaiah Venu ${ }^{1} \cdot$ Perumal Velmayil $^{2}$ \\ Received: 2 May 2020 / Accepted: 16 January 2021 / Published online: 23 February 2021 \\ (C) The Author(s) 2021
}

\begin{abstract}
The study examines about the red sand dune deposit locally designated as teri deposits; it is an omnipresent geomorphologic feature present in the coastal region of Thoothukudi and Ramanathapuram districts of Tamil Nadu, India. One of the inland teri sand dune outcrops is located around the Kuthiraimozhi village of Thoothukudi district in Tamil Nadu, India. Textural, mineralogical and geochemical studies were carried out in the teri sediments and its compact sandstone outcrops. The sediments are moderately sorted to well-sorted and finely skewed nature which indicates that fluvio-marine depositional environment. Geochemical analysis results of major, trace and rare earth elements for teri deposits help to predict the provenance, weathering status, depositional environment and climate. The geochemical study reveals that the sediments were derived from marine and non-marine sources. Teri sediments are geochemically classified as lithic arenite or wacke. Petrography and X-ray diffraction analysis reveal the predominance of quartz and feldspars along with the accessory minerals like ilmenite, rutile, garnet, magnetite, hematite, zircon, diopside, hypersthenes and biotite. Mineralogical observation illustrates that the teri sediments have originated from the weathering of felsic and mafic source rocks. The Chemical Index of Alteration (CIA) values of sediments represent moderate to the high status of weathering conditions in the source area. The depositional environment indicates that the sediments are fine-grained with high maturity index. Despite that the sediments are formed by fluvio-marine sources, the reddening character in the teri deposits is due to oxidation and leaching of iron-bearing minerals by percolating surface water from high rainfall and groundwater fluctuation of the aquifer under arid and semi-arid climate conditions.
\end{abstract}

Keywords Teri sand $\cdot$ Textural analysis $\cdot$ Petrography $\cdot$ Heavy minerals $\cdot$ Oxidation

\section{Introduction}

The recent and sub-recent red sediments (or) locally called as 'teri' sediments are ubiquitous linear geomorphologic features in the coastal region of Thoothukudi and Ramanathapuram districts of Tamil Nadu, India. These features occur as detached patches of amidst black soil and loamy soil. The thickness of these red deposits

Responsible Editor: Domenico M. Doronzo

Perumal Velmayil

geo6perumal@gmail.com

1 Department of Geology, V.O.C College (affiliated to M.S University, Tirunelveli), Thoothukudi 628008, India

2 Department of Geology, Alagappa University, Karaikudi 630003, India generally decreases from northeast to southwest direction. Based on the occurrences, teri deposits are categorized as coastal teri, midland and inland teri deposits. The inland teri deposit is located as a surficial outcrop at the contact zone of metamorphic and sedimentary rocks. The top surface of the teri deposit is generally loose and unconsolidated, whereas the bottom bed is compact, consolidated and form as a red sandstone bed.

Due to more evaporation processes, the groundwater makes calcrete deposit as veining and replacement within the teri sediments. The origin of teri sediment was geologically under debate. Numerous researchers, not only in India, but also in various parts of the world, have concentrated their research on sediment texture, mineralogy and geochemistry (Cox et al. 1995; McLennan 1993; Angusamy and Rajamanickam 2000; Behera 2003; Angusamy et al. 2004; Poppe and Eliason 2008; Dayal 
and Moorthy 2006; Ramaswamy and Rao 2006; Islam and Rahman 2009; Udayanapillai et al. 2015, 2016; Ashraf and Hoque 2015; Zaid 2015; Hendrik et al. 2015; Miao et al. 2016; Mir and Mir 2019; ArmstrongAltrin 2020; Perumal and Udayanapillai 2020; RamosVazquez and Armstrong-Altrin 2020; Armstrong-Altrin et al. 2020; Madhavaraju et al. 2020). Thiruvikramji et al. (2008) stated that red coloration of Sathankulam teri deposits is caused by Holocene climate change. Udayanapillai and Ganeshamoorthy (2013) found that teri deposit of Surangudi area in Thoothukudi district of Tamil Nadu was derived from black soil. Red coloration of the deposit may be due to leaching action and oxidation of iron-bearing heavy minerals by rainfall and groundwater. Since teri deposit is highly enriched with heavy mineral concentration, many private sectors occupy and establish their mining sites for sand mining; an attempt has been made to infer the texture, mineralogy and geochemistry of the Kuthiraimozhi teri sediments.

\section{Study area}

The location map of the study area is shown in Fig. 1. The proposed research area bounds between latitudes from $8^{\circ} 15^{\prime} 0^{\prime \prime} \mathrm{N}$ to $9^{\circ} 25^{\prime} 0^{\prime \prime} \mathrm{N}$ and longitudes from $77^{\circ} 05^{\prime} 0^{\prime \prime} \mathrm{E}$ to $78^{\circ} 35^{\prime} 0^{\prime \prime} \mathrm{E}$. The study area is well connected by national and state highway road network from Tuticorin, Tirunelveli and Tiruchendur. The physiography is almost flat with little elevation ranges from 5 to $62 \mathrm{~m}$ above MSL. Drainage density is low, and its pattern is sub-dendritic nature. Southern branch of Tamirabarani and Karamanayar rivers flows in the north and south directions respectively to the study area. The area shows strong tectonic evidence of both progradation and upliftment. The elevated teri sand dune feature of the Kuthiraimozhi region acts as a good groundwater potential zone in the coastal plain. The average rainfall of the study area is approximately $700 \mathrm{~mm}$, influenced by southwest and northeast monsoons.

\section{Geology}

Proterozoic rocks such as quartzite, crystalline limestone, hornblende-biotite gneiss, charnockite, granitic gneiss, granite and pegmatite occur as basement rocks. The basement rocks are overlain by Tertiary and Quaternary shell limestone and arenaceous limestone outcrops, respectively. Tertiary and Quaternary beds are followed by Holocene to Pleistocene laterite and calcrete. Recent and sub-recent black soil, red (teri) soil, river alluvium and beach sand rest on sub-surface Quaternary and Tertiary outcrops.

\section{Material and methods}

A total of ten representative spatial teri sand samples, including sub-surface compact sandstone, were collected from the dune outcrop of Kuthiraimozhi region. Then, $200 \mathrm{-g}$ sediment samples were subjected to sieve analysis for $15 \mathrm{~min}$ by using the Ro-Tap sieve shaker machine using a stack of quarter phi intervals, such as 10,18, 35, 60,120, 230 and 400 ASTM sieves. Each fraction was weighed. Graphical measures, such as histogram and cumulative frequency against weight percentage of data, were drawn. Basic geostatistical parameters, such as mean, median, standard deviation, skewness and kurtosis, were calculated by the formulae of Folk and ward (1957). The selected samples of fine fraction retained from 120 to 230 mesh materials were taken for heavy mineral analysis. The heavy minerals were separated from light fraction by using heavy liquids bromoform (Milner 1962). The separated heavy minerals were identified through a camera attached polarised binocular microscope. The prepared thin section of the selected compact red sandstone was also photographed for petrographic analysis. The selected two representative samples are powdered teri sediments that were subjected to Xray diffraction analysis (XRD) through the instruments 'Xpertpro' from the laboratory of the Department of Physics, M.S University, Tirunelveli. Mineralogy of the samples was identified through respective spacing values and their intensity (Sachinathmitra 1989) and also from other published literatures. Major, trace and rare earth elements were analysed by X-ray fluorescence (XRF) and inductively coupled plasma mass spectrometry (ICPMS) instruments respectively from National Geophysical Research Institute, Hyderabad.

\section{Results and discussion}

The results and discussion of grain size analysis, mineralogy and major, minor or trace and rare earth elements geochemistry of teri sediments of Kuthiraimozhi region are given as follows.

\section{Grain size analysis}

The results of the grain size analysis of the teri sediments are given in (Table 1). The grain size analysis data of teri sediments are obtained from the graphical measures of the histogram and cumulative frequency curves. The histogram shows most of the sediments of the area are uni-modal distribution (Fig. 2a-j.). The uni-modal distribution of grain size indicates the uniform mixing of grains (Verma and Prasad 1974). The cumulative frequency curve depicts the relationship between sediment transport dynamics and grain size distribution. The cumulative frequency curves of the teri sediments of the area are given in Fig. 3a-j. 


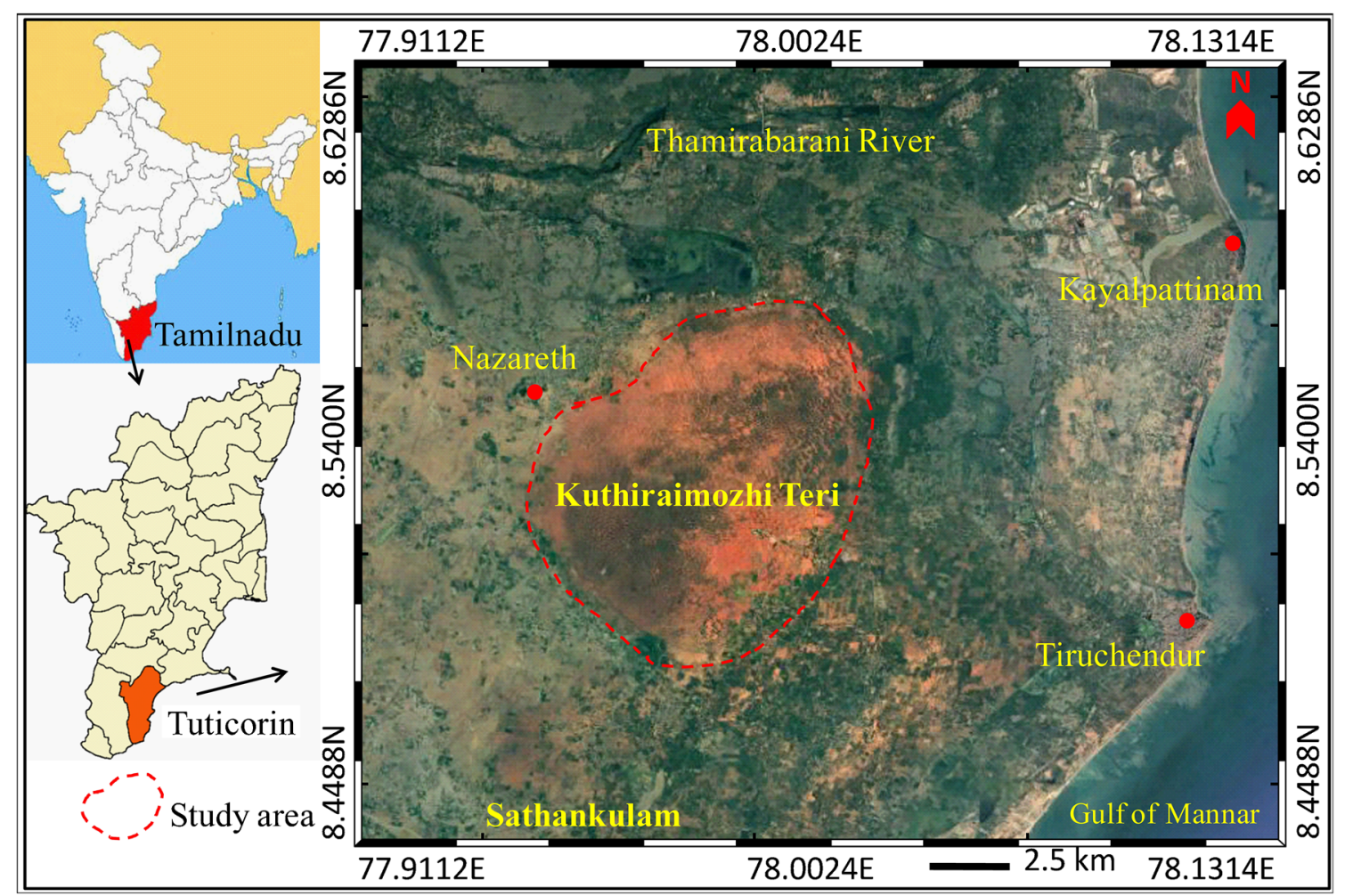

Fig. 1 Location map of the study area

The graphical measurement results of mean (0.62 to 2.03), median ( 0.6 to1.8), standard deviation (0.04 to 0.96$)$, skewness ( 0.34 to 1.78$)$, and kurtosis ( 0.61 to 0.78 ) values ranges are respectively. Sorting nature of sediments is from wellsorted to moderately sort. Skewness results shows +ve skewed in nature, whereas the kurtosis class is platykurtic. Moderately sorted to well-sorted nature indicates the fluvio-marine depositional environment (Friedman 1961; Folk and Ward 1957). Such a similar condition had existed in the study area. Negative and positive skewed sediments indicate erosion and deposition, respectively (Cronan 1972). The positive skewness, platykurtic nature and fine-grained characteristics of sediments indicate that sediments are brought from both fluvial and marine environment. The classificatory environmental study of standard deviation and graphic mean illustrate the depositional environments of the sediments; the area has river and coastal dune environment (Friedman 1961; Moiola and Weiser 1968).

\section{Mineralogical observation}

The teri sediments consist of ninety percentage of light minerals and ten percentage of heavy minerals. The heavy minerals are controlled by lithology of source rock, differential stability of the minerals, the durability of minerals on long abrasion, hydrodynamic factor, shape and specific gravity and post-depositional survival character.
Numerous researchers have worked on heavy mineral studies of coastal sediments (Angusamy and Rajamanickam 2000; Behera 2003, Angusamy et al. 2004; Ergin et al. 2007; Verma and Prasad 1974; Perumal and Udayanapillai 2015; Miao et al. 2016; Ramasamy and Rao 2006). The petrographical study and XRD analysis reveal the mineralogical content, such as ilmenite, magnetite, rutile, garnet, zircon, diopside, tourmaline, hematite, goethite, kyanite and along with light minerals, such as quartz, feldspar and biotite (Fig. 4 (a, b); Table 2). Mineralogy reveals that teri sediment has originated early as fluvial black soil regolith deposits derived from the source rock of quartzite, calc-granulite, khondalite, charnockite, granite, etc. The sediments may be transported by the fluvial action of Tamirabarani and Karamaniyar rivers. The iron-rich heavy minerals, such as ilmenite, magnetite, garnet, hypersthene and rutile, in the soil, undergo leaching first by meteoric or surface water and groundwater fluctuation of the aquifer and then leads to oxidation process in situ, due to favourable arid and semi-arid climatic conditions. This above two actions cause for reddening colour of the teri soil. The presence of spherical and sub-spherical quartz indicates that the sediments have a long transformational history, due to the fluvial action. The presence of angular and sub-angular grains may be due to less transport history by the adjacent coastal wind action from the Gulf of Mannar region (Fig. 5a-d). 
Table 1 Textural data for the teri sediments (Folk and Word 1957)

\begin{tabular}{|c|c|c|c|c|c|c|c|c|}
\hline Sample & Mean & Standard deviation & Skewness & Kurtosis & Median & Std. deviation class & Skewness class & Kurtosis class \\
\hline 1 & 2.03 & 0.04 & 0.59 & 0.8 & 2.1 & Very well sorted & Fine skewed & Platykurtic \\
\hline 2 & 1.63 & 0.44 & 1.78 & 0.74 & 1.65 & Well sorted & Fine skewed & Platykurtic \\
\hline 3 & 1.77 & 0.88 & 1.75 & 0.8 & 1.75 & Moderately sorted & Fine skewed & Platykurtic \\
\hline 4 & 1.23 & 0.56 & 0.46 & 0.77 & 1.3 & Moderately well sorted & Fine skewed & Platykurtic \\
\hline 5 & 1.78 & 0.96 & 0.41 & 0.72 & 1.8 & Moderately sorted & Fine skewed & Platykurtic \\
\hline 6 & 1.83 & 0.8 & 0.56 & 0.74 & 1.8 & Moderately sorted & Fine skewed & Platykurtic \\
\hline 7 & 1.95 & 0.39 & 0.36 & 0.69 & 0.65 & Well sorted & Fine skewed & Platykurtic \\
\hline 8 & 0.68 & 0.43 & 0.38 & 0.61 & 0.65 & Well sorted & Fine skewed & Very platykurtic \\
\hline 9 & 0.62 & 0.42 & 0.34 & 0.7 & 0.6 & Well sorted & Fine skewed & Platykurtic \\
\hline 10 & 1.85 & 0.37 & 0.34 & 0.75 & 0.65 & Well sorted & Fine skewed & Platykurtic \\
\hline
\end{tabular}

Fig. $2 \mathbf{a}-\mathbf{j}$ The histogram of the teri sediments showing uni-modal distribution
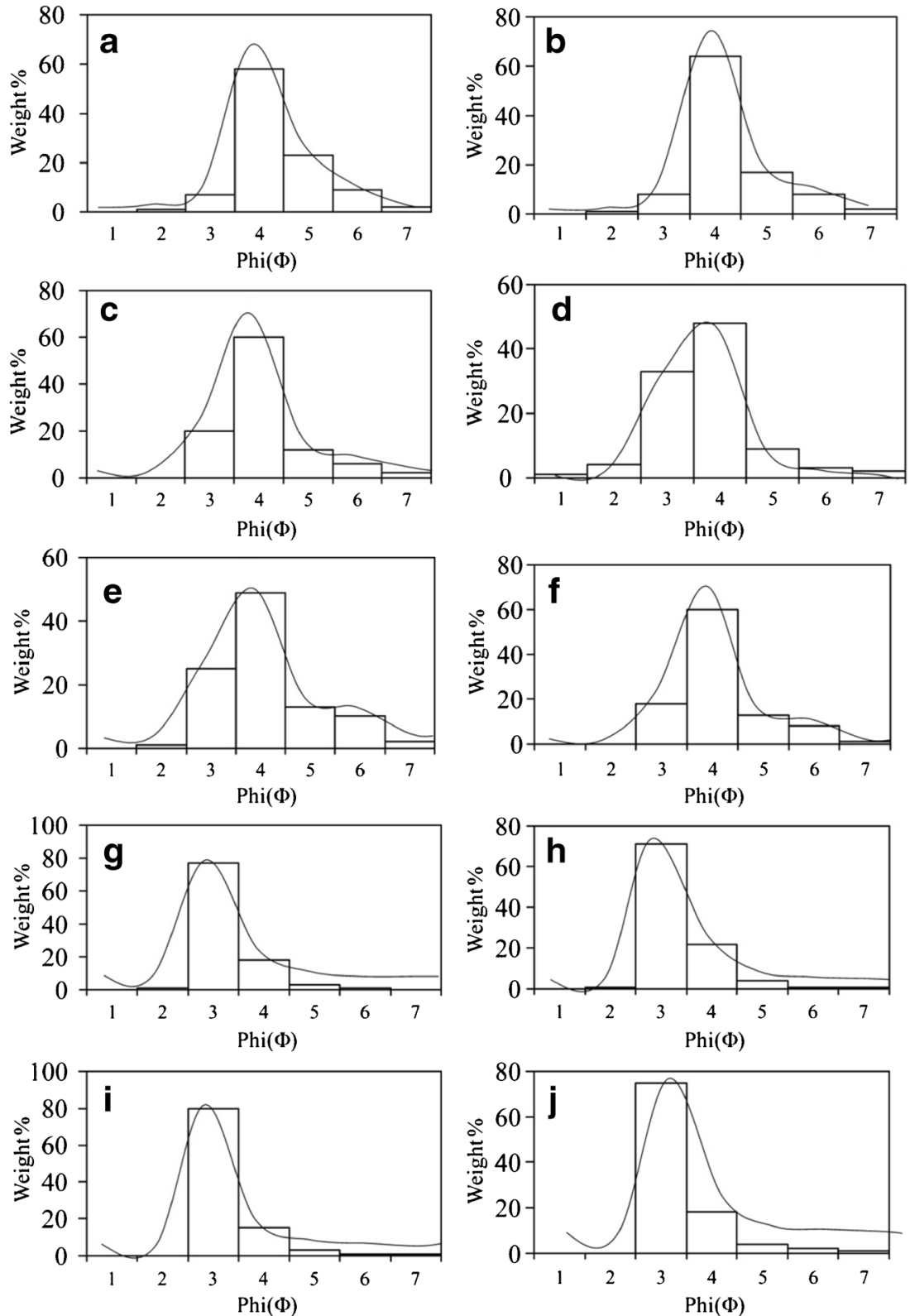
Fig. 3 a-j The cumulative frequency curve for the teri sediments showing grain size distributions (Visher 1969)
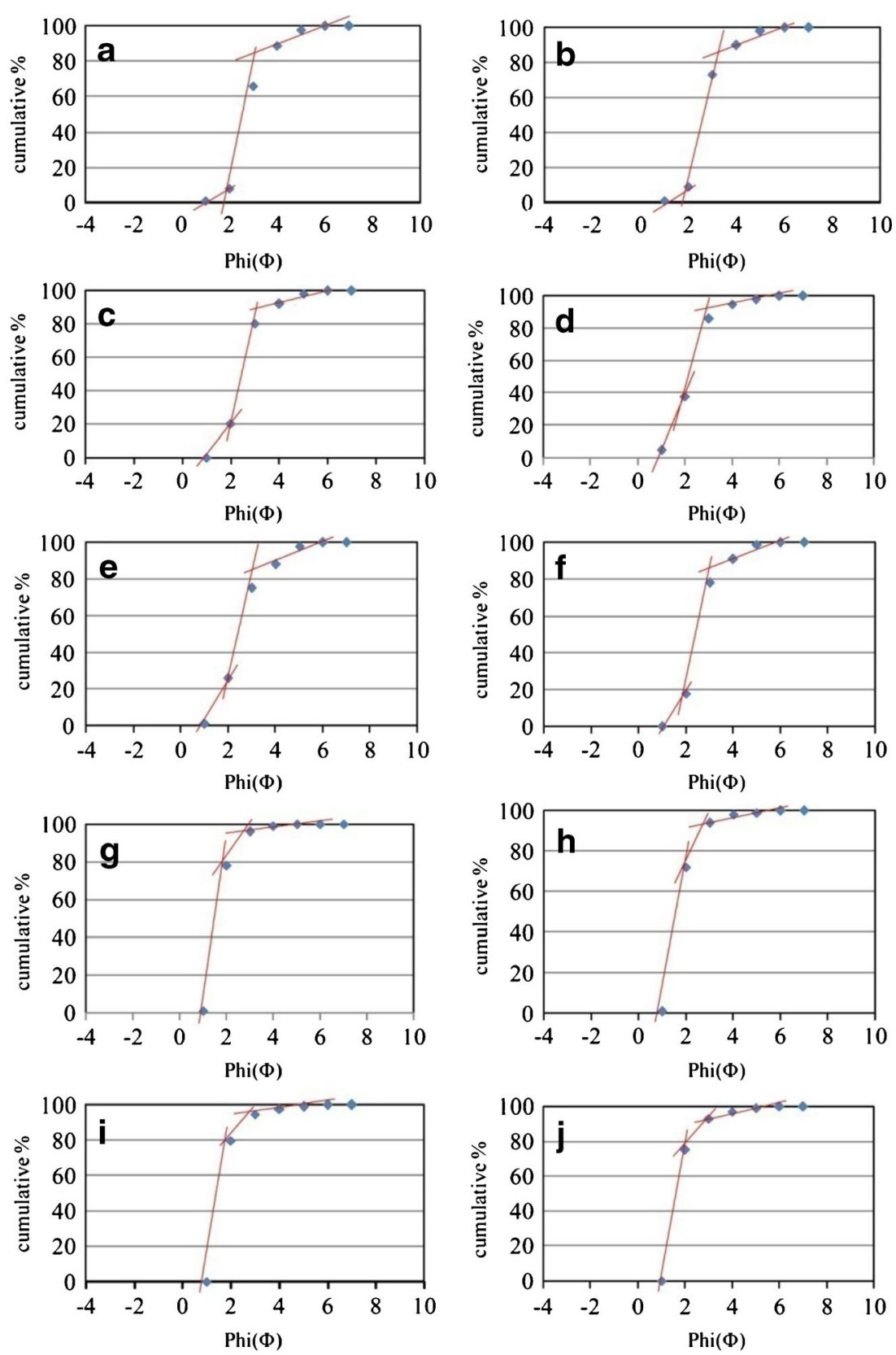

These above observations support the evidential characteristics of the sediments as fluvio-marine origin. The veining character of calcrete in teri sand may be due to the evapotranspiration process of alkaline-rich groundwater originated from the sources of the calcareous sandstone aquifer of Tertiary and Quaternary sedimentary basement rocks below red teri soil.

\section{Geochemistry}

The results of major, trace and rare earth elements of teri sediments are shown in Tables 3, 4, and 5.

\section{Major elements}

The average distribution trend of major elements of the area is given in Fig. 6a and Table 3. $\mathrm{SiO}_{2}, \mathrm{Al}_{2} \mathrm{O}_{3}, \mathrm{Fe}_{2} \mathrm{O}_{3}, \mathrm{~K}_{2} \mathrm{O}$ and $\mathrm{TiO}_{2}$ concentrations are above $1 \%$, whereas the remaining oxides, viz. $\mathrm{MnO}, \mathrm{MgO}, \mathrm{CaO}, \mathrm{Na}_{2} \mathrm{O}$ and $\mathrm{P}_{2} \mathrm{O}_{5}$, are below $1 \%$. The result shows a similar distribution trend.

The average $\mathrm{SiO}_{2}$ and $\mathrm{Al}_{2} \mathrm{O}_{3}$ contents of teri sediments of the area have $61.44 \%$ and $11.10 \%$, respectively. The concentration of $\mathrm{Al}$ is related to a good measure of transported flux (Armstrong-Altrin et al. 2019; Nagarajan et al. 2007). $\mathrm{SiO}_{2}$ vs $\mathrm{Al}_{2} \mathrm{O}_{3}$ shows a high degree of positive correlation $(r=0.84)$ that could have derived from the same sources. The 
concentration of $\mathrm{SiO}_{2}$ is more than $\mathrm{Al}_{2} \mathrm{O}_{3}$ due to the supply of unaltered quartz and feldspar from the sources by fluvial action of Thamiraparani River and coastal wind. $\mathrm{SiO}_{2}$ and $\mathrm{Al}_{2} \mathrm{O}_{3}$ are generally obtained from weathering products of various silicates. Orthoclase $\left(\mathrm{KAlSi}_{3} \mathrm{O}_{8}\right)$ is formed by isomorphous substitution of $\mathrm{Si}^{4+}$ with $\mathrm{Al}^{3+}$ because of their identical ionic radii $(0.50 \AA$ and $0.55 \AA$, respectively). Alkali metals are introduced to compensate for the changes as in the formation of $\mathrm{K}$ feldspar in which $25 \%$ of $\mathrm{Si}^{4+}$ has been replaced by $\mathrm{Al}$. The clay minerals are hydrous aluminium silicate and a variety of heavy minerals formed by partial isomorphic substitution $\mathrm{Si}^{4+}$ with a variety of ions, via $\mathrm{Be}^{2+}, \mathrm{Al}^{3+}, \mathrm{Al}^{3}, \mathrm{Fe}^{2-}, \mathrm{Mg}^{2}$ ${ }^{-}, \mathrm{Ca}^{2-}$, etc. Hence, in sediments, the percentage of alumina is incomparable with that of Silica (Vetha Roy and Chandrasekar 2007). But the negative correlation of $\mathrm{Al}_{2} \mathrm{O}_{3}$ vs $\mathrm{SiO}_{2}$ in teri sand of the Surangudi region in Thoothukudi district represents that it may be derived from different sources (Udayanapillai and Ganesamoorthy 2013).

The $\mathrm{K}_{2} \mathrm{O} / \mathrm{Al}_{2} \mathrm{O}_{3}$ ratio reveals the original composition of sediments. The $\mathrm{K}_{2} \mathrm{O} / \mathrm{Al}_{2} \mathrm{O}_{3}$ ratios for clay minerals and feldspar are different ( 0 to $0.2 ; 0.3$ to 0.9 ) in sediments, respectively (Cox et al. 1995). The average result of the $\mathrm{K}_{2} \mathrm{O} / \mathrm{Al}_{2} \mathrm{O}_{3}$ ratio of the area is 0.10 which is closer to the clay mineral contents. It suggests that Kaolin or Illite may be dominant minerals from the sediments. The $\mathrm{SiO}_{2} / \mathrm{Al}_{2} \mathrm{O}_{3}$ and $\mathrm{SiO}_{2} /$ $\mathrm{MgO}$ ratios of Proterozoic Pakhal Shale represent the ratio values of 3.35 and 31.3 , respectively, which suggest a fairly good amount of felsic sources in the provenance (Dayal and Moorthy 2006). But the result of $\mathrm{SiO}_{2} / \mathrm{Al}_{2} \mathrm{O}_{3}$ and $\mathrm{SiO}_{2} / \mathrm{MgO}$ ratios in the area show different values such as 5.54 and 698.20 respectively which suggest mixing of felsic and mafic rock sources (Ramos-Vázquez and Armstrong-Altrin 2019).

The correlations between $\mathrm{Fe}_{2} \mathrm{O}_{3}$ vs $\mathrm{MnO}, \mathrm{Fe}_{2} \mathrm{O}_{3}$ vs $\mathrm{CaO}$, $\mathrm{Fe}_{2} \mathrm{O}_{3}$ vs $\mathrm{Na}_{2} \mathrm{O}, \mathrm{Fe}_{2} \mathrm{O}_{3}$ vs $\mathrm{K}_{2} \mathrm{O}, \mathrm{Fe}_{2} \mathrm{O}_{3}$ vs $\mathrm{TiO}_{2}$ and $\mathrm{Fe}_{2} \mathrm{O}_{3}$ vs $\mathrm{P}_{2} \mathrm{O}_{5}$ show positive correlations respectively which indicates derived from lithogenic sources. The negative correlation between $\mathrm{Fe}_{2} \mathrm{O}_{3}$ vs $\mathrm{MgO}$ represents the indication of different sources. $\mathrm{MgO}$ may be derived from the association of calcrete sources of groundwater origin, whereas $\mathrm{Fe}_{2} \mathrm{O}_{3}$ may be derived from the lithogenic sources from iron-bearing minerals of igneous and metamorphic rocks. $\mathrm{TiO}_{2}$ is mainly obtained from phyllosilicates (Condie et al., 1992; Nagarajan et al., 2007). It represents source rock, due to its immobility character (McLennan 1993; Nagarajan et al. 2007). The average value of $\mathrm{TiO}_{2}$ is $1.10 \%$. $\mathrm{TiO}_{2}$ vs $\mathrm{Al}_{2} \mathrm{O}_{3}$ shows a very low degree of negative correlation $(r=-0.19)$. So, they are independent
Fig. 4 (a, b) X-ray diffraction patterns of the teri sediments

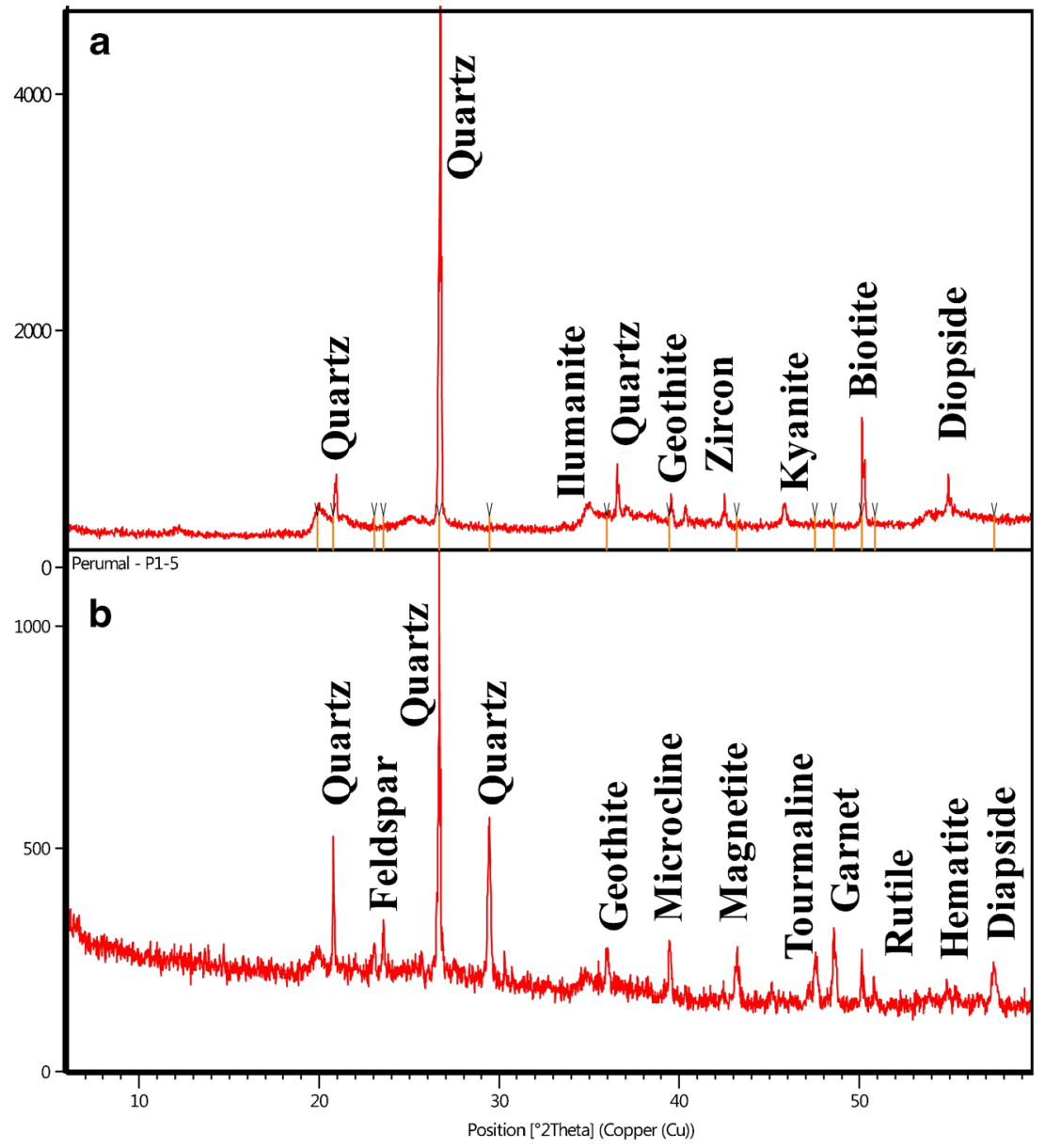


Table 2 XRD data for the teri sediments

\begin{tabular}{|c|c|c|c|c|c|}
\hline SL. no. & Name of the minerals & \multicolumn{2}{|c|}{ Observed $\mathrm{Z} \theta$ value } & \multicolumn{2}{|c|}{ D-spacing angle } \\
\hline 1. & Quartz & $\begin{array}{l}21.28 \\
27.01 \\
39.89 \\
46.15 \\
50.129 \\
60.09\end{array}$ & $\begin{array}{l}36.60 \\
39.61 \\
42.50 \\
45.85 \\
50.17\end{array}$ & $\begin{array}{l}4.17 \\
3.30 \\
2.26 \\
1.966 \\
1.818 \\
1.538\end{array}$ & $\begin{array}{l}2.454 \\
2.275 \\
2.127 \\
1.97 \\
1.818\end{array}$ \\
\hline 2. & Microcline & $\begin{array}{l}40.69 \\
50.640\end{array}$ & & $\begin{array}{l}2.216 \\
1.802\end{array}$ & \\
\hline 3. & Biotite & $\begin{array}{l}26.717 \\
54.995 \\
60.05\end{array}$ & & $\begin{array}{l}3.336 \\
1.669 \\
1.540\end{array}$ & \\
\hline 4. & Ilmenite & $\begin{array}{l}32.721 \\
35.427 \\
53.249\end{array}$ & & $\begin{array}{l}2.736 \\
2.533 \\
1.720\end{array}$ & \\
\hline 5. & Rutile & 68.66 & & 1.366 & \\
\hline 6. & Kyanite & 67.837 & & 1.381 & \\
\hline 7. & Diopside & $\begin{array}{l}73.84 \\
73.549\end{array}$ & & $\begin{array}{l}1.283 \\
1.287\end{array}$ & \\
\hline 8. & Goethite & $\begin{array}{l}36.95 \\
40.387\end{array}$ & & $\begin{array}{l}2.432 \\
2.233\end{array}$ & \\
\hline 9. & Hematite & $\begin{array}{l}64.31 \\
64.154\end{array}$ & & $\begin{array}{l}1.448 \\
1.457\end{array}$ & \\
\hline 10. & Magnetite & 42.885 & & 2.108 & \\
\hline 11. & Tourmaline & 55.19 & & 1.664 & \\
\hline
\end{tabular}

variables derived from different sources. Most of the samples have low $\mathrm{P}_{2} \mathrm{O}_{5}$ content which may be a lesser amount of accessory minerals, such as apatite and monazite.

The $\mathrm{Ca}$ and $\mathrm{Mg}$ are widely distributed in the earth's crust. $\mathrm{CaO}$ is the greater importance in the biosphere. So, it is also classified as biophile elements. $\mathrm{CaO}$ vs $\mathrm{Na}_{2} \mathrm{O}, \mathrm{K}_{2} \mathrm{O}, \mathrm{TiO}_{2}$ and $\mathrm{P}_{2} \mathrm{O}_{5}$ represent positive correlations. The coefficient values of $r=0.59,0.97,0.86$ and 0.70 , respectively. These positive correlations represent the same lithogenic association of mineral sources. Positive correlations of $\mathrm{Na}_{2} \mathrm{O}$ vs $\mathrm{K}_{2} \mathrm{O}$, $\mathrm{Na}_{2} \mathrm{O}$ vs $\mathrm{TiO}_{2}, \mathrm{~K}_{2} \mathrm{O}$ vs $\mathrm{TiO}_{2}$ and $\mathrm{K}_{2} \mathrm{O}$ vs $\mathrm{P}_{2} \mathrm{O}_{5}$ suggest that they are derived from the same lithogenic sources. The teri sand occurs as an in situ isolated deposit amidst black soil and loamy soil. Red coloration may be due to leaching and oxidation of iron-bearing mineral under favourable climatic conditions (Udayanapillai and Ganesamoorthy 2013). Such similar action may cause the reddening coloration of the teri sediments.
Fig. 5 Petrography of compact teri sandstone. a Angular Quartz covered with red ferruginous cement, b Ilmenite and spherical and sub spherical Quartz in ferruginous cement, c Angular Quartz with altered hypersthene mineral in ferruginous cement, $\mathbf{d}$ Hornblende, quartz and rock fragments bordered with ferruginous cement
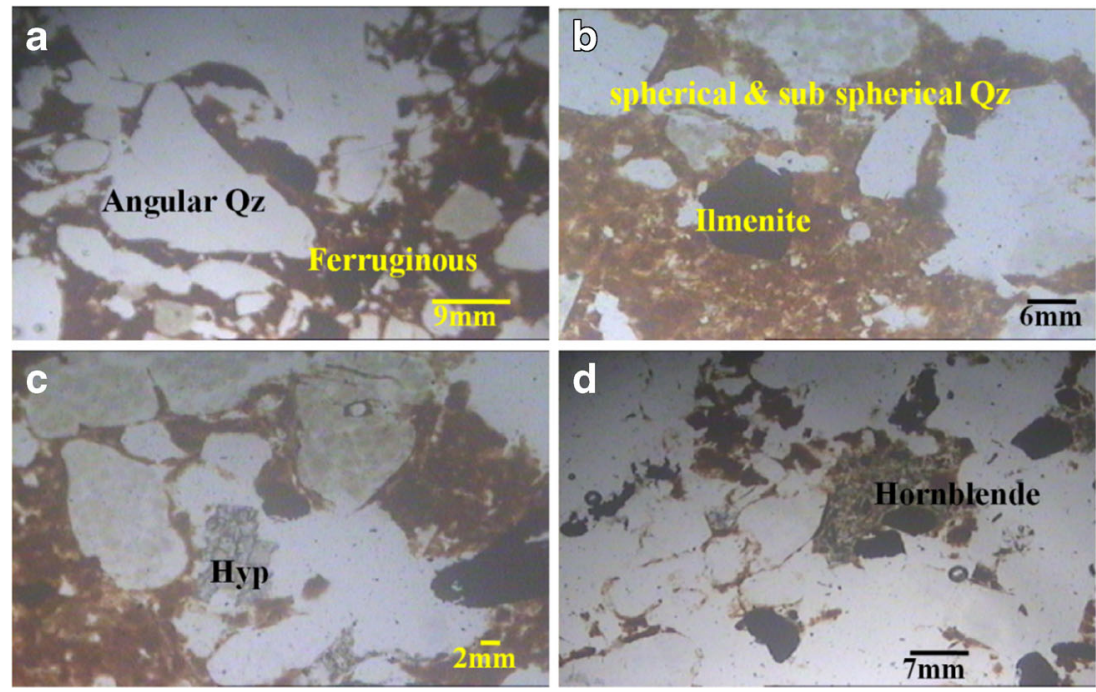
Table 3 Major element (\%) concentration for the teri sediments and Post-Archean Australian shale (PAAS)

\begin{tabular}{|c|c|c|c|c|c|c|c|c|c|c|c|c|}
\hline Major elements & 1 & 2 & 3 & 4 & 5 & 6 & 7 & 8 & 9 & 10 & Avg & PAAS \\
\hline $\mathrm{SiO}_{2}$ & 62.10 & 60.15 & 61.30 & 61.70 & 60.17 & 62.80 & 61.70 & 60.80 & 63.20 & 60.50 & 61.44 & 62.40 \\
\hline $\mathrm{Al}_{2} \mathrm{O}_{3}$ & 11.70 & 10.28 & 10.80 & 11.30 & 10.31 & 11.60 & 11.30 & 11.13 & 11.50 & 11.07 & 11.10 & 18.80 \\
\hline $\mathrm{Fe}_{2} \mathrm{O}_{3}$ & 3.55 & 3.56 & 3.73 & 3.80 & 3.68 & 3.70 & 3.62 & 2.79 & 2.86 & 2.64 & 3.39 & 1.00 \\
\hline $\mathrm{MnO}$ & 0.08 & 0.07 & 0.06 & 0.08 & 0.07 & 0.06 & 0.07 & 0.04 & 0.05 & 0.03 & 0.06 & 7.00 \\
\hline $\mathrm{MgO}$ & 0.10 & 0.08 & 0.07 & 0.06 & 0.07 & 0.05 & 0.12 & 0.12 & 0.10 & 0.11 & 0.09 & 1.20 \\
\hline $\mathrm{CaO}$ & 1.18 & 1.19 & 1.16 & 1.15 & 1.20 & 1.16 & 1.18 & 0.22 & 0.36 & 0.18 & 0.90 & 2.00 \\
\hline $\mathrm{Na}_{2} \mathrm{O}$ & 0.20 & 0.17 & 0.30 & 0.40 & 0.16 & 0.18 & 0.16 & 0.09 & 0.15 & 0.08 & 0.19 & 1.20 \\
\hline $\mathrm{K}_{2} \mathrm{O}$ & 1.16 & 1.11 & 1.18 & 1.15 & 1.15 & 1.12 & 1.17 & 0.90 & 0.84 & 0.80 & 1.06 & 3.68 \\
\hline $\mathrm{TiO}_{2}$ & 1.17 & 1.14 & 1.16 & 1.17 & 1.17 & 1.14 & 1.14 & 1.08 & 0.90 & 0.88 & 1.10 & 0.16 \\
\hline $\mathrm{P}_{2} \mathrm{O}_{5}$ & 0.06 & 0.04 & 0.03 & 0.05 & 0.05 & 0.06 & 0.03 & 0.03 & 0.02 & 0.02 & 0.04 & 0.16 \\
\hline $\mathrm{K}_{2} \mathrm{O} / \mathrm{Na}_{2} \mathrm{O}$ & 5.80 & 6.53 & 3.93 & 2.88 & 7.19 & 6.22 & 7.31 & 10.00 & 5.60 & 10.00 & 5.60 & 3.09 \\
\hline $\mathrm{SiO}_{2} / \mathrm{Al}_{2} \mathrm{O}_{3}$ & 5.31 & 5.85 & 5.68 & 5.46 & 5.84 & 5.41 & 5.46 & 5.46 & 5.50 & 5.47 & 5.54 & 3.32 \\
\hline $\mathrm{SiO}_{2} / \mathrm{MgO}$ & 621.00 & 751.88 & 875.71 & 1028.33 & 859.57 & 1256.00 & 514.17 & 506.67 & 632.00 & 550.00 & 698.20 & 31.20 \\
\hline $\mathrm{K}_{2} \mathrm{O} / \mathrm{AI}_{2} \mathrm{O}_{3}$ & 0.10 & 0.11 & 0.11 & 0.10 & 0.11 & 0.10 & 0.10 & 0.08 & 0.07 & 0.07 & 0.10 & 0.20 \\
\hline $\mathrm{Al}_{2} \mathrm{O}_{3} / \mathrm{TiO}_{2}$ & 10.00 & 9.02 & 9.31 & 9.66 & 8.81 & 10.15 & 9.91 & 10.31 & 12.78 & 12.58 & 10.13 & 19.00 \\
\hline $\mathrm{Al}_{2} \mathrm{O}_{3} / \mathrm{K}_{2} \mathrm{O}$ & 10.09 & 9.26 & 9.15 & 9.83 & 8.97 & 10.36 & 9.66 & 12.37 & 13.69 & 13.84 & 10.49 & 5.11 \\
\hline $\mathrm{MgO} / \mathrm{Al}_{2} \mathrm{O}_{3}$ & 0.01 & 0.01 & 0.01 & 0.01 & 0.01 & 0.00 & 0.01 & 0.01 & 0.01 & 0.01 & 0.01 & 0.64 \\
\hline $\mathrm{Na}_{2} \mathrm{O} / \mathrm{K} 2 \mathrm{O}$ & 0.17 & 0.15 & 0.25 & 0.35 & 0.14 & 0.16 & 0.14 & 0.10 & 0.18 & 0.10 & 0.18 & 0.33 \\
\hline $\mathrm{K}_{2} \mathrm{O} / \mathrm{AI}_{2} \mathrm{O}_{3}$ & 0.10 & 0.11 & 0.11 & 0.10 & 0.11 & 0.10 & 0.10 & 0.08 & 0.07 & 0.07 & 0.10 & 0.20 \\
\hline $\mathrm{MgO} / \mathrm{Al}_{2} \mathrm{O}_{3}$ & 0.01 & 0.01 & 0.01 & 0.01 & 0.01 & 0.00 & 0.01 & 0.01 & 0.01 & 0.01 & 0.01 & 0.06 \\
\hline
\end{tabular}

\section{Trace elements}

The average distribution of trace elements of teri sediments is presented in Fig. $6 \mathrm{~b}$ and Table 4. V, Cr, Ni, Cu, Zn, Rb, S, Zr, $\mathrm{Nb}$ and $\mathrm{Ba}$ elements are concentrated higher above 10ppm, whereas other elements Sc, Co, Ga, Y, Cs, Hf, Ta, Pb, Th and $\mathrm{U}$ contents are less in a concentration below 10ppm. The values $\mathrm{Ga}, \mathrm{Y}, \mathrm{Nb}, \mathrm{Cs}, \mathrm{Hf}, \mathrm{Ta}, \mathrm{Pb}$ and $\mathrm{U}$ contents are less below $10 \%$.

Based on geochemical affinity, the trace elements are classified as (1) Large Ion Lithophile Elements (LILE)- $\mathrm{Rb}, \mathrm{Sr}$, $\mathrm{Cs}$ and $\mathrm{Ba}$; (2) Ferro Magnesian Trace Elements (FMTE) $\mathrm{Sc}, \mathrm{V}, \mathrm{Cr}, \mathrm{Co}, \mathrm{Ni}, \mathrm{Cu}, \mathrm{Zn}, \mathrm{Ga}$ and $\mathrm{Pb}$; and (3) High Field Strength Elements (HFSE) - Y, Zr, Nb, Ta, HF, TH and U. The very high concentration of trace elements of the sediment shows the ascending trends of $\mathrm{Zr}>\mathrm{Rb}>\mathrm{Ba}>\mathrm{V}>\mathrm{Zn}>\mathrm{Cr}>$ $\mathrm{Sr}$ as $28.00>40.00>41.10>57.00>57.30>73.60$ and $>$ 82.8 , respectively. The presence of more zirconium in red sediments may be derived from the heavy mineral zircon derived from the sources of granite and charnockite rocks from the adjacent terrain. The occurrences of zircon crystal in granite and charnockite have already been reported from the adjacent area of Sathankulam region of Tamil Nadu (Perumal 2017). $\mathrm{Rb}$ is a strongly lithophile element and alkali metal which is also available from the potash feldspar, viz., orthoclase and microcline minerals. These sources may be obtained from the granite and pegmatite source rocks. The high content
$\mathrm{Ba}$ in sediments is normally derived from barite crystals of syn-sedimentary origin (Armstrong-Altrin et al. 2019; Nagarajan et al. 2007; Udayanapillai et al. 2020). So, the syngenetic deposition of barium concentration may cause for the Ba sources in red teri sediments. Vanadium is a lithophile element and abundant in association with apatite, biotite, muscovite, magnetite, pyroxene and amphibole. The presence of ' $V$ ' in soil depends on parent rock (Shaheen et al. 2019). The weathering of this mineral available in granite, hornblendebiotite gneiss and charnockite in the study area may contribute to the ' $V$ ' concentration to the red teri sediments. Vanadium content in a sedimentary rock reflects the primary abundance of detrital ferric oxide, clay minerals, hydroxide of $\mathrm{Fe}$ and $\mathrm{Mn}$ (Meunier 1994). So, iron-bearing minerals may also contribute 'V' to the teri sediments. The geogenic Zn sources may be derived from the plagioclase and microcline mineral contents from granitic rocks. Chromium is a lithophile element. It is associated with the minerals of iron-bearing silicates, such as diopside, hypersthene, biotite, hornblende, magnetite and inclusion in quartz. It makes isomorphous substitution in aluminium and ferric spinel, given closer ionic radii $(\mathrm{Cr}=0.64 \AA)$ to that of $(\mathrm{Al}=0.57 \AA)$ and $(\mathrm{Fe}=0.67 \AA)$ (Dhir et al. 2004). High concentration of chromium content has been observed from the beach sands of Central coast of Ghana (Mahamuda and Emmanuel 2020). Bijilal and Senthil Nathan (2016) established that $\mathrm{Cr}$ is more available in the lateritic clay profile in Kerala. Reduction of chromium and iron by kaolin, 
Table 4 Trace element concentrations (in ppm) for the teri sediments Post Australian Archean Shale (PAAS) values are from Taylor and McLennan (1985)

\begin{tabular}{|c|c|c|c|c|c|c|c|c|c|c|c|c|}
\hline Trace elements & 1 & 2 & 3 & 4 & 5 & 6 & 7 & 8 & 9 & 10 & Sample & PAAS \\
\hline $\mathrm{Sc}$ & 10.03 & 7.08 & 9.10 & 8.45 & 10.64 & 8.96 & 11.46 & 11.42 & 6.51 & 7.93 & 9.16 & 16.00 \\
\hline V & 54.12 & 57.32 & 53.04 & 51.23 & 63.63 & 58.50 & 62.64 & 60.72 & 57.56 & 55.43 & 57.42 & 150.00 \\
\hline $\mathrm{Cr}$ & 77.63 & 73.93 & 71.53 & 69.75 & 74.92 & 71.00 & 71.51 & 75.64 & 77.81 & 78.48 & 74.22 & 110.00 \\
\hline $\mathrm{Co}$ & 7.34 & 6.72 & 8.73 & 9.45 & 6.02 & 6.51 & 7.90 & 7.10 & 5.92 & 5.51 & 7.12 & 23.00 \\
\hline $\mathrm{Ni}$ & 23.51 & 22.67 & 21.51 & 21.34 & 22.01 & 24.92 & 21.43 & 21.00 & 20.46 & 20.03 & 21.89 & 55.00 \\
\hline $\mathrm{Cu}$ & 17.90 & 15.81 & 14.85 & 18.83 & 16.62 & 19.46 & 18.61 & 18.75 & 21.46 & 19.60 & 18.19 & 50.00 \\
\hline $\mathrm{Zn}$ & 58.21 & 55.83 & 60.76 & 61.94 & 51.37 & 59.25 & 57.94 & 56.29 & 56.93 & 60.57 & 57.91 & 85.00 \\
\hline $\mathrm{Ga}$ & 8.00 & 7.09 & 6.71 & 8.53 & 8.18 & 7.21 & 8.38 & 6.92 & 8.33 & 9.41 & 7.88 & 0.00 \\
\hline $\mathrm{Rb}$ & 40.64 & 42.01 & 41.92 & 39.44 & 41.47 & 41.07 & 43.53 & 39.30 & 37.65 & 37.59 & 40.46 & 160.00 \\
\hline $\mathrm{Sr}$ & 83.87 & 81.20 & 85.95 & 83.63 & 85.37 & 84.41 & 82.59 & 81.49 & 80.43 & 84.51 & 83.35 & 200.00 \\
\hline $\mathrm{Y}$ & 8.35 & 8.71 & 6.58 & 7.96 & 9.62 & 9.46 & 9.41 & 8.21 & 6.93 & 9.59 & 8.48 & 0.00 \\
\hline $\mathrm{Zr}$ & 27.72 & 29.03 & 26.95 & 25.02 & 27.06 & 28.73 & 29.72 & 30.02 & 28.32 & 31.30 & 28.39 & 210.00 \\
\hline $\mathrm{Nb}$ & 15.31 & 14.35 & 13.24 & 12.53 & 14.50 & 18.59 & 13.36 & 12.70 & 16.41 & 13.02 & 14.40 & 2.00 \\
\hline Cs & 0.60 & 1.32 & 1.02 & 2.00 & 2.25 & 2.41 & 2.31 & 2.12 & 2.71 & 2.49 & 1.92 & 0.00 \\
\hline $\mathrm{Ba}$ & 41.71 & 44.21 & 41.74 & 45.92 & 41.64 & 41.40 & 39.80 & 42.31 & 40.47 & 40.46 & 41.97 & 650.00 \\
\hline $\mathrm{Hf}$ & 2.85 & 2.93 & 3.49 & 3.90 & 2.54 & 3.53 & 2.16 & 2.47 & 3.62 & 3.59 & 3.11 & 5.00 \\
\hline $\mathrm{Ta}$ & 2.83 & 1.04 & 2.18 & 2.46 & 2.35 & 2.74 & 2.03 & 2.52 & 2.94 & 1.74 & 2.28 & 0.00 \\
\hline $\mathrm{Pb}$ & 7.48 & 8.10 & 6.86 & 7.97 & 9.53 & 9.28 & 9.10 & 8.73 & 9.81 & 8.52 & 8.54 & 0.00 \\
\hline Th & 8.50 & 7.26 & 7.86 & 6.50 & 7.34 & 7.90 & 7.35 & 5.18 & 6.97 & 6.28 & 7.11 & 15.00 \\
\hline $\mathrm{U}$ & 1.03 & 1.30 & 2.68 & 2.21 & 1.58 & 2.10 & 2.32 & 2.21 & 1.02 & 2.16 & 1.86 & 3.00 \\
\hline $\mathrm{La} / \mathrm{Sc}$ & 1.60 & 2.15 & 1.53 & 1.60 & 1.07 & 1.65 & 1.41 & 1.50 & 3.00 & 1.95 & 1.74 & 0.02 \\
\hline $\mathrm{Th} / \mathrm{Sc}$ & 0.85 & 1.03 & 0.86 & 0.77 & 0.69 & 0.88 & 0.64 & 0.45 & 1.07 & 0.79 & 0.80 & 7.00 \\
\hline $\mathrm{La} / \mathrm{Th}$ & 1.89 & 2.09 & 1.77 & 2.08 & 1.55 & 1.87 & 2.19 & 3.31 & 2.81 & 2.46 & 2.20 & 0.00 \\
\hline $\mathrm{Zr} / \mathrm{Hf}$ & 9.73 & 9.91 & 7.72 & 6.42 & 10.65 & 8.14 & 13.76 & 12.15 & 7.82 & 8.72 & 9.50 & 2.40 \\
\hline $\mathrm{Cr} / \mathrm{Ni}$ & 3.30 & 3.26 & 3.33 & 3.27 & 3.40 & 2.85 & 3.34 & 3.60 & 3.80 & 3.92 & 3.41 & 42.00 \\
\hline $\mathrm{Cr} / \mathrm{Th}$ & 9.13 & 10.18 & 9.10 & 10.73 & 10.21 & 8.99 & 9.73 & 14.60 & 11.16 & 12.50 & 10.63 & 2.00 \\
\hline $\mathrm{Th} / \mathrm{Co}$ & 1.16 & 1.08 & 0.90 & 0.69 & 1.22 & 1.21 & 0.93 & 0.73 & 1.18 & 1.14 & 1.02 & 75.00 \\
\hline $\mathrm{Th} / \mathrm{Cr}$ & 0.11 & 0.10 & 0.11 & 0.09 & 0.10 & 0.11 & 0.10 & 0.07 & 0.09 & 0.08 & 0.10 & 0.60 \\
\hline $\mathrm{U} / \mathrm{Th}$ & 0.12 & 0.18 & 0.34 & 0.34 & 0.22 & 0.27 & 0.32 & 0.43 & 0.15 & 0.34 & 0.27 & 0.10 \\
\hline $\mathrm{V} / \mathrm{Cr}$ & 0.70 & 0.78 & 0.74 & 0.73 & 0.85 & 0.82 & 0.88 & 0.80 & 0.74 & 0.71 & 0.77 & 1.40 \\
\hline $\mathrm{Ni} / \mathrm{Cr}$ & 0.30 & 0.31 & 0.30 & 0.31 & 0.29 & 0.35 & 0.30 & 0.28 & 0.26 & 0.26 & 0.30 & 2.40 \\
\hline $\mathrm{Cu} / \mathrm{Zn}$ & 0.31 & 0.28 & 0.24 & 0.30 & 0.32 & 0.33 & 0.32 & 0.33 & 0.38 & 0.32 & 0.31 & 0.60 \\
\hline
\end{tabular}

montmorillonite and illite minerals has been proved experimentally (Songjong Kwaka et al. 2018). The Sr content may be contributed from calcrete, shell limestone and calcgranulite rocks from the adjacent terrain. $\mathrm{Sr}$ is not correlated with other trace elements. It must be associated with $\mathrm{Ca}$. Positive correlations of $\mathrm{Zr}$ vs $\mathrm{Cr}, \mathrm{Ta}, \mathrm{Rb}$ vs $\mathrm{Sc}, \mathrm{Ta}, \mathrm{Ba}$ vs $\mathrm{Co}, \mathrm{V}$ vs $\mathrm{Y}, \mathrm{Pb}, \mathrm{Zr}$ vs $\mathrm{Cr}$ and $\mathrm{Cr}$ vs $\mathrm{Zr}$ are derived from the similar sources.

\section{Rare earth elements}

Rare earth element concentration of the teri sediments of the analysed samples is given in Table 5. The chondrite normalized (Taylor and McLennan 1985) plot for teri sediments is given in Fig. 6c. Rare earth elements generally reside in the fine fraction, such as silt and clay. The clay minerals enriched with alumina and ferric ion may readily accommodate the trivalent rare earth elements (Cullers et al., 1988; Babu 2017; Armstrong-Altrin et al. 2019; Perumal and Udayanapillai 2019). The REE plot of the red teri soil from the area shows a slightly high LREE and flat HREE pattern with negative europium anomaly. It indicates the red sediments derived from the terrestrial or continental source rock. The $(\mathrm{La} / \mathrm{Yb})$ red teri sediments of the area are of higher values (average 17.75) than the $(\mathrm{La} / \mathrm{Yb}) \mathrm{n}$ values of average chondrite value, and further, the values are equal to the values of $(\mathrm{La} /$ $\mathrm{Yb}$ )n of granitoid basement rocks (Armstrong-Altrin et al. 2019; Perumal 2017). So, the red sediment may be derived 
Table 5 Rare earth element concentrations (in ppm) for the teri sediments/Average chondrite values are from Taylor and McLennan (1985)

\begin{tabular}{|c|c|c|c|c|c|c|c|c|c|c|c|}
\hline REE & 1 & 2 & 3 & 4 & 5 & 6 & 7 & 8 & 9 & 10 & Average \\
\hline $\mathrm{La}$ & 16.03 & 15.19 & 13.92 & 13.49 & 11.35 & 14.75 & 16.13 & 17.13 & 19.56 & 15.45 & 15.30 \\
\hline $\mathrm{Ce}$ & 31.58 & 33.76 & 24.57 & 32.00 & 32.57 & 30.35 & 29.03 & 29.97 & 31.86 & 34.56 & 31.03 \\
\hline $\operatorname{Pr}$ & 4.52 & 2.47 & 2.84 & 2.75 & 3.35 & 2.00 & 3.85 & 4.32 & 2.78 & 3.23 & 3.21 \\
\hline $\mathrm{Nd}$ & 11.85 & 13.00 & 8.38 & 9.34 & 8.67 & 7.13 & 8.46 & 10.33 & 14.13 & 8.30 & 9.96 \\
\hline $\mathrm{Sm}$ & 2.57 & 1.90 & 1.70 & 1.75 & 1.73 & 1.90 & 1.70 & 2.00 & 1.70 & 1.60 & 1.86 \\
\hline $\mathrm{Eu}$ & 0.54 & 0.55 & 0.51 & 0.53 & 0.57 & 0.56 & 0.55 & 0.54 & 0.52 & 0.48 & 0.54 \\
\hline Gd & 2.31 & 2.27 & 2.23 & 2.23 & 2.21 & 2.24 & 2.23 & 2.20 & 2.13 & 2.12 & 2.22 \\
\hline $\mathrm{Tb}$ & 0.22 & 0.23 & 0.28 & 0.26 & 0.24 & 0.26 & 0.25 & 0.23 & 0.21 & 0.23 & 0.24 \\
\hline Dy & 1.23 & 1.22 & 1.23 & 1.21 & 1.19 & 1.21 & 1.20 & 1.20 & 1.18 & 1.16 & 1.20 \\
\hline Ho & 0.43 & 0.40 & 0.40 & 0.42 & 0.46 & 0.47 & 0.41 & 0.40 & 0.41 & 0.39 & 0.42 \\
\hline $\mathrm{Er}$ & 0.67 & 0.62 & 0.61 & 0.61 & 0.64 & 0.59 & 0.64 & 0.70 & 0.70 & 0.65 & 0.64 \\
\hline $\mathrm{Tm}$ & 0.14 & 0.15 & 0.12 & 0.12 & 0.17 & 0.19 & 0.17 & 0.18 & 0.17 & 0.15 & 0.16 \\
\hline $\mathrm{Yb}$ & 0.85 & 0.86 & 0.81 & 0.81 & 0.86 & 0.88 & 0.85 & 0.90 & 0.80 & 0.79 & 0.84 \\
\hline $\mathrm{Lu}$ & 0.15 & 0.12 & 0.16 & 0.17 & 0.16 & 0.15 & 0.17 & 0.18 & 0.17 & 0.17 & 0.16 \\
\hline $\mathrm{Eu} / \mathrm{Eu}^{*}$ & 2.44 & 2.09 & 1.97 & 1.99 & 1.97 & 2.07 & 1.97 & 2.10 & 1.92 & 1.86 & 2.04 \\
\hline$(\mathrm{La} / \mathrm{Yb}) \mathrm{n}$ & 18.86 & 17.66 & 17.19 & 16.65 & 13.20 & 16.76 & 18.98 & 19.03 & 24.45 & 19.56 & 18.23 \\
\hline$(\mathrm{La} / \mathrm{Sm}) \mathrm{n}$ & 6.24 & 7.99 & 8.19 & 7.71 & 6.56 & 7.76 & 9.49 & 8.57 & 11.51 & 9.66 & 8.37 \\
\hline$(\mathrm{Gd} / \mathrm{Yb}) \mathrm{n}$ & 2.72 & 2.64 & 2.75 & 2.75 & 2.57 & 2.55 & 2.62 & 2.44 & 2.66 & 2.68 & 2.64 \\
\hline
\end{tabular}

from granitoid source terrain. The positive anomaly of Ce and negative anomaly of the Eu of teri sediments of the area is

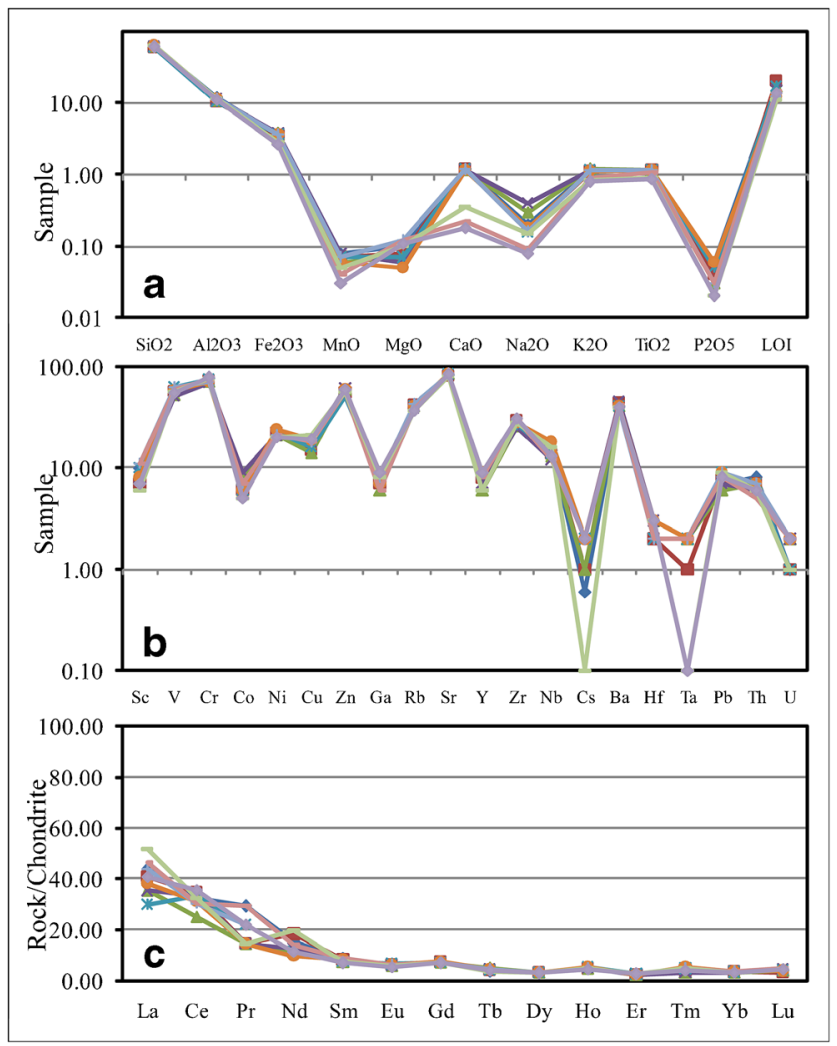

Fig. 6 a The average distribution trend of Major elements (Wt. \%) of teri sediments, $\mathbf{b}$ The distribution of trace elements (in ppm) of teri sediments. c Rare earth elements concentration of the teri sediments similar to the value of granite terrain sources (ArmstrongAltrin et al. 2019). It indicates that study area sediments were also derived from granitoid basement sources.

\section{Classifications}

Classifications of sediments are established by the value of the $\log \left(\mathrm{SiO}_{2} / \mathrm{Al}_{2} \mathrm{O}_{3}\right)$ vs $\log \left(\mathrm{Na}_{2} \mathrm{O} / \mathrm{K}_{2} \mathrm{O}\right)$ ratio of their respective sediments (Pettijohn 1975; Armstrong-Altrin et al. 2004; Islam and Rahman 2009; Madhavaraju and Lee 2010). The same above composition of teri sediments in the study area falls on the field of lithic arenite consists of quartz and feldspar and rock fragments with fine clay matrix in which the grain size is from 0.06 to $2 \mathrm{~mm}$. Wacke is also a sandstone composed of sand-sized grains of 0.063 to $2 \mathrm{~mm}$ with a finegrained clay matrix.

\section{Provenance}

The provincial characteristics of any sediment are found by using the geochemical signature of clastic sediments (Taylor and McLennan 1985; Condie et al. 1992; Cullers 1995; Madhavaraju and Ramasamy 2002; Armstrong Altrin et al. 2004; Perumal and Udayanapillai 2019). $\mathrm{Al}_{2} \mathrm{O}_{3} / \mathrm{TiO}_{2}$ ratio of clastic rocks is generally used to know the source rock composition. Hayashi et al. (1997) found that the ratio of $\mathrm{Al}_{2} \mathrm{O}_{3} /$ $\mathrm{TiO}_{2}$ of the sediment increases from 3 to 8 derived from mafic igneous rock sources, from 8 to 21 derived from intermediate igneous rock sources and from 21 to 70 derived from felsic igneous rocks. The $\mathrm{Al}_{2} \mathrm{O}_{3} / \mathrm{TiO}_{2}$ ratio of the area studied ranges 
from 9.02 to 12.78 and with an average value of 10.13. It indicates that the basement rocks granite, pyroxene granulite or charnockite, hornblende-biotite gneiss, khondalite and quartzite rocks may be the probable source rocks for these sediments. Such a similar result has been reported in the Surangudi teri deposit of Thoothukudi region (Udayanapillai and Ganesamoorthy 2013). The range of identity values of $\mathrm{Al}_{2} \mathrm{O}_{3} / \mathrm{TiO}_{2}$ from 15 to 25 for shales and sandstones of Precambrian age has been reported from the Hammant series of Egypt (Willis et al. 1988). The average $\mathrm{Al}_{2} \mathrm{O}_{3} / \mathrm{TiO}_{2}$ ratio of Garudamangalam sandstone is reported as 15.73 (Babu 2017). The average $\mathrm{Al}_{2} \mathrm{O}_{3} / \mathrm{TiO}_{2}$ ratio of Rabanapillai shales is mentioned as 21.3 which suggests the probable source rocks of felsic granitoid rock (Anaya Gregorio et al. 2018). The average $\mathrm{Al}_{2} \mathrm{O}_{3} / \mathrm{TiO}_{2}$ ratio of calcareous gray shales of Uttatur stage, Upper Cretaceous, is 40, which indicates that the felsic igneous rocks, such as granite, hornblende-biotite gneiss and acid and intermediate charnockite, must be the probable source rocks (Perumal and Udayanapillai 2019). The bivariate plots (Fig. 7a; Floyd et al. 1989; Anaya Gregorio et al. 2018), between $\mathrm{TiO}_{2}$ vs $\mathrm{Ni}$, further indicate that the teri sediments were mainly derived from felsic or acidic granitoid basement rocks (Fig. 8).

The $\mathrm{Cr}$ and $\mathrm{Ni}$ are abundant in silicic clastic provenance (Nagarajan et al. 2007). Cr and Ni ratio in teri sediments of the area are somewhat higher (Table 5) value than other minor/ trace elements. But the $\mathrm{Cr} / \mathrm{Ni}$ ratio of teri sediment is low (3.44) compared with PAAS value (42.00). Despite the sediments derived from the granitoid basement, the in situ leaching and oxidation process of iron-bearing heavy minerals and silicate minerals in teri sand dunes of the area under favourable climate causes for reddening character and also represent $\mathrm{Ni}$ and $\mathrm{Cr}$ abundance in the sediments.

$\mathrm{Th} / \mathrm{Co}$ and $\mathrm{La} / \mathrm{Sc}$ ratio of the teri sediments of the study area falls on the plot diagram of Fig. 7b (Cullers 2002) of silicic rock composition. These results indicate that the teri sediments are derived from the source rocks of granite, charnockite, hornblende biotite gneiss and quartzite.

The elemental ratios of $\mathrm{Th} / \mathrm{Sc}, \mathrm{Th} / \mathrm{Co}, \mathrm{Th} / \mathrm{Cr}, \mathrm{Cr} / \mathrm{Th}$ and $\mathrm{La} / \mathrm{Sc}$ of the results are $0.79,1.03,0.09,11.34$ and 1.8 , respectively. They are compared with the data of Garudamangalam sandstone (Babu 2017), Upper continental crust (UCC, Taylor and McLennan 1985), Post Australian Archean Shale (PAAS) (Taylor and McLennan 1985) and the range of sediments value of felsic rocks and mafic rocks (Table 6). This comparison also represents that the teri sediment values have coincided within the range of felsic rocks. The $\mathrm{La} / \mathrm{Th}$ and $\mathrm{Th} / \mathrm{Sc}$ are quite constant in sedimentary rocks as 2.4 and 0.9 , respectively (Taylor and McLennan 1985; Anaya Gregorio et al. 2018; Perumal and Udayanapillai 2019). The $\mathrm{La} / \mathrm{Th}$ and $\mathrm{Th} / \mathrm{Sc}$ ratios of teri sediments are 2.31 and 1.03 , respectively. These ratios are coincided with the values of sources of silicic or felsic rock composition.
The REE pattern and Europium anomaly will represent an important clue about the source rock character (ArmstrongAltrin 2020). Higher LREE/HREE ratios and negative Eu anomalies are generally observed in felsic rocks, whereas lower LREE/HREE ratio and no or small anomaly are observed in mafic rocks (Cullers 1995). The average LREE/HREE ratio of teri sediments of the study area is 13.35 and the negative Eu anomaly as 2.01 . These results are higher than the above ratio of mafic rocks and it represents that the teri sediments are derived from the felsic source rocks, such as granite and charnockite. The Eu/Eu* vs $(\mathrm{Gd} / \mathrm{Yb})$ n plot (Fig. 7c); (McLennan and Taylor 1991) indicate the teri sediment of the area plot fall on the Archean field. So, it is originated from Archean granite, granitic gneiss and charnockite rocks of the study area.

\section{Chemical Index of Alteration and weathering}

Nesbitt and Young (1982) established the Chemical Index of Alteration (CIA) values using the chemical molecular composition of bulk sediments as given by the following formula.
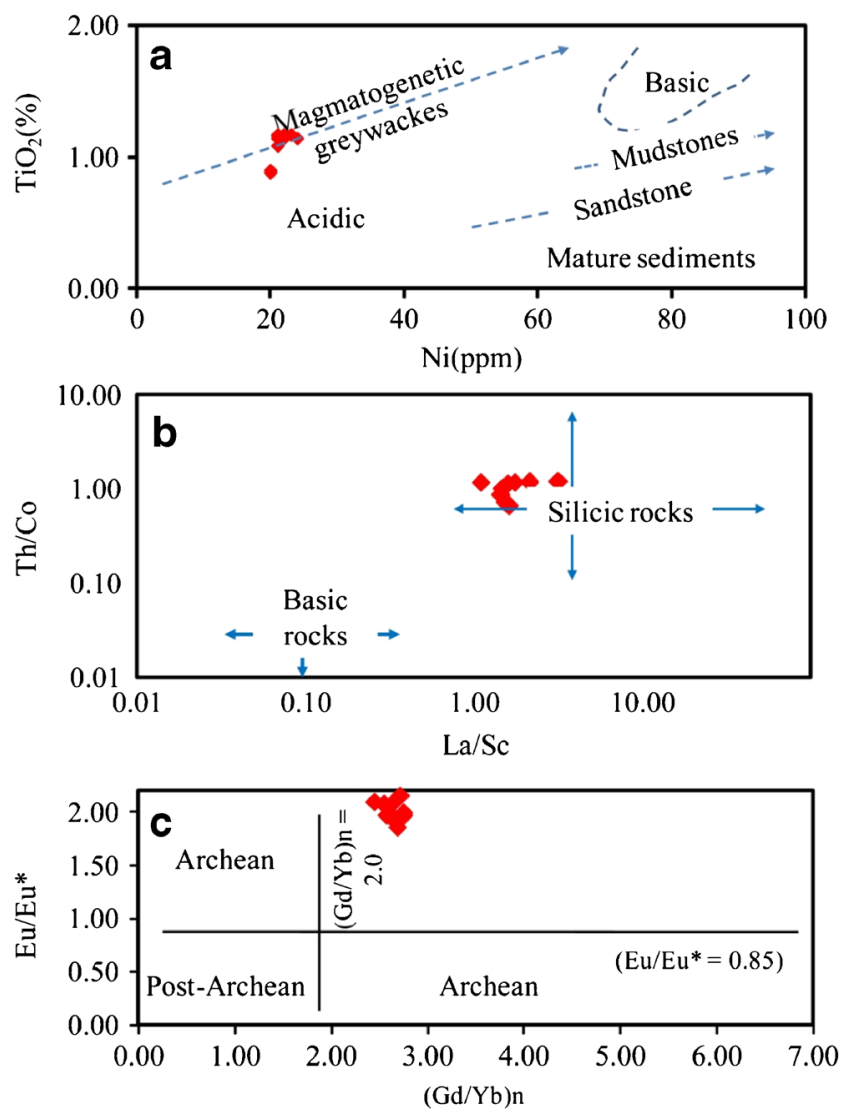

Fig. 7 a $\mathrm{TiO}_{2}$ vs Ni bivariate provenance plot for teri sediments (after Floyed et al. 1989; Nagarajan et al. 2007), b Th/Co vs La/Sc ratio provenance plot derived by after Cullers, (2002), latter followed by Nagarajan et al. (2007), c $(\mathrm{Gd} / \mathrm{Yb}) n$ vs $\left(\mathrm{Eu} / \mathrm{Eu}^{*}\right)$ ratio provenance plot of the teri sediments ( after Taylor and McLennan, 1985) 


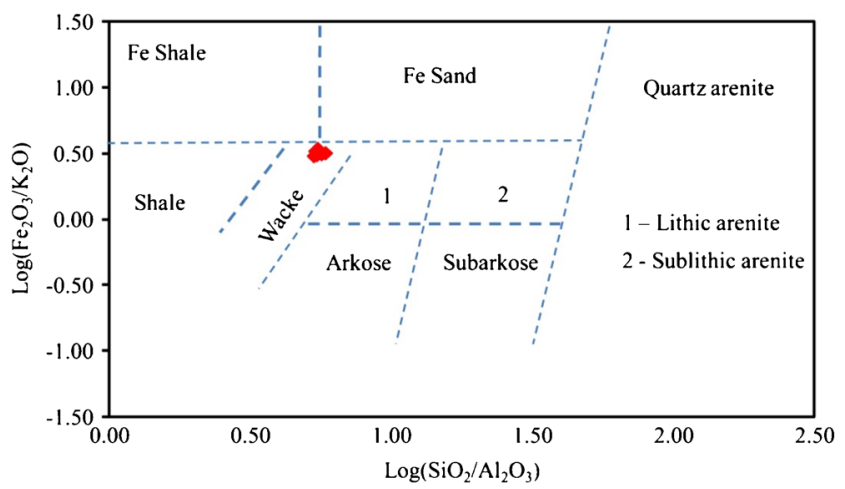

Fig. 8 Geochemical classification for the samples of the teri sediments $\log \left(\mathrm{SiO}_{2} / \mathrm{Al}_{2} \mathrm{O}_{3}\right)$ vs $\log \left(\mathrm{Fe}_{2} \mathrm{O}_{3} / \mathrm{K}_{2} \mathrm{O}\right)$ diagram (after Madhavaraju and Lee (2010)

$$
\mathrm{CIA}=\mathrm{Al}_{2} \mathrm{O}_{3} /\left(\mathrm{Al}_{2} \mathrm{O}_{3}+\mathrm{CaO} *+\mathrm{Na}_{2} \mathrm{O}+\mathrm{K}_{2} \mathrm{O}\right) \times 100
$$

in which $\mathrm{CaO}^{*}$ represents silicate phase value. CIA value $100 \%$ represents for kaolin and chlorite, 70-75 for average shale. The high values 76-100 represent an index of chemical weathering in the source area. The low values (50 or less) of CIA indicate low weathering of the source area. The average CIA value of the teri sediments represents the $84 \%$. It indicates intense chemical weathering, and the low $\mathrm{Na}_{2} \mathrm{O}$ also represents high weathering of source rock (Fig. 9).

\section{Depositional environment and climate}

Sediments containing higher $\mathrm{Al}_{2} \mathrm{O}_{3} / \mathrm{Na}_{2} \mathrm{O}$ and $\mathrm{K}_{2} \mathrm{O} / \mathrm{Na}_{2} \mathrm{O}$ ratio and low $\mathrm{CaO}$ represent fine-grained clastic sediments that are chemically matured. Dayal and Moorthy (2006) and Suttner and Dutta (1986) have proposed a climate boundary classification based on the total geochemical value of $\mathrm{Al}_{2} \mathrm{O}_{3}+$ $\mathrm{K}_{2} \mathrm{O}+\mathrm{Na}_{2} \mathrm{O}$ vs $\mathrm{SiO}_{2}$ ratio The results of the teri sediments indicate semi-arid to arid climate with high maturity index. Such a similar result existed in the Surangudi teri sediments.

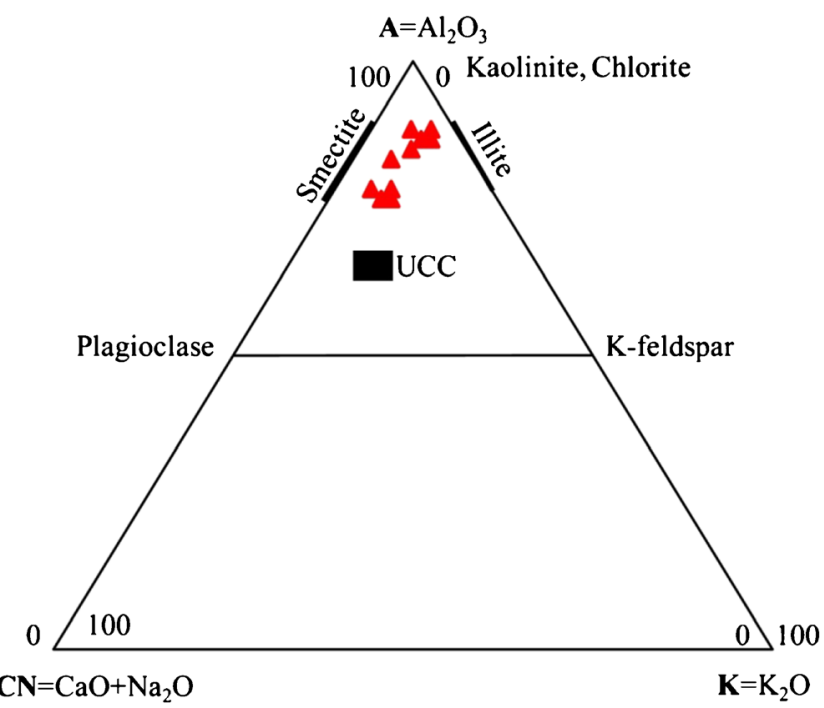

Fig. 9 A-CN-K triangular plot after Nesbitt and Young (1982) of the area (UCC; Taylor and McLennan 1985)

The classification based on $\log \left(\mathrm{MgO} / \mathrm{Al}_{2} \mathrm{O}\right)$ vs $\log \left(\mathrm{K}_{2} \mathrm{O} /\right.$ $\mathrm{Al}_{2} \mathrm{O}_{3}$ ) (Roaidest 1978; Armstrong-Altrin et al. 2004; Shehata and Abdou 2008) ratio depicts the depositional environment of sediments belonging to marine and non-marine origin. This interpretation is coincided with the petrography results.

\section{Conclusion}

Textural characteristics of sediments reveal that moderately sorted to well-sorted fine skewed and platykurtic nature are represent the mixture of river and coastal dune environment. The thin section study and XRD analysis reveal less mineralogical contents of ilmenite, rutile, garnet, magnetite, hematite, zircon, diopside, hypersthene, biotite and hornblende along with an abundance of quartz and feldspar. The sediments are derived from the felsic and mafic source rocks of the adjacent
Table 6 The range of elemental ratios of teri sediments compared with the ratios in similar fractions derived from felsic and mafic rocks, upper continental crust (UCC) and Post-Archean Australian Shale (PAAS)

\begin{tabular}{|c|c|c|c|c|c|}
\hline \multirow{2}{*}{$\begin{array}{l}\text { Elemental } \\
\text { ratio }\end{array}$} & \multirow{2}{*}{$\begin{array}{l}\text { Range of teri sand from the } \\
\text { Kuthiraimozhi formation }{ }^{1}\end{array}$} & \multicolumn{2}{|c|}{ Range of sediments ${ }^{2}$} & \multirow{2}{*}{$\begin{array}{l}\text { Upper } \\
\text { Continental } \\
\text { Crust }^{3}\end{array}$} & \multirow{2}{*}{$\begin{array}{l}\text { Post-Archean } \\
\text { Australian } \\
\text { average Shale }\end{array}$} \\
\hline & & $\begin{array}{l}\text { Felsic } \\
\text { rocks }\end{array}$ & Mafic rocks & & \\
\hline $\mathrm{Th} / \mathrm{Sc}$ & $0.45-1.03$ & $0.84-20.5$ & $0.05-0.22$ & 0.79 & 0.9 \\
\hline $\mathrm{Th} / \mathrm{Co}$ & $0.69-1.22$ & $0.67-19.4$ & $0.04-1.4$ & 0.63 & 0.63 \\
\hline $\mathrm{Th} / \mathrm{Cr}$ & $0.07-0.11$ & $0.13-2.7$ & $0.018-0.046$ & 0.13 & 0.13 \\
\hline $\mathrm{Cr} / \mathrm{Th}$ & $8.99-14.60$ & $4.00-15$ & $25-500$ & 7.76 & 7.53 \\
\hline $\mathrm{La} / \mathrm{Sc}$ & $1.07-3.00$ & $2.5-16.3$ & $0.43-0.86$ & 2.21 & 2.4 \\
\hline
\end{tabular}

\footnotetext{
${ }^{1}$ This study

${ }^{2}$ Cullers (1995, 2002); Cullers and Podkovyrov (2000); Cullers et al. (1988)

${ }^{3}$ Taylor and McLennan (1985)
} 
study area and from coastal wind sources of beach sand of the Gulf of Mannar. The geochemistry of the sediments reveals the abundance of elements of $\mathrm{SiO}_{2}, \mathrm{Fe}_{2} \mathrm{O}_{3}, \mathrm{MgO}, \mathrm{CaO}, \mathrm{TiO}_{2}$, $\mathrm{V}, \mathrm{Cr}, \mathrm{Ni}, \mathrm{Cu}, \mathrm{Zn}, \mathrm{Rb}, \mathrm{Sr}, \mathrm{Zr}, \mathrm{Nb}$ and $\mathrm{Ba}$ light rare earth elements with negative europium and positive cerium anomalies. Despite teri sediments are derived from fluvio-marine sources; the in situ leaching and oxidation process of ironbearing heavy minerals and silicate minerals cause the reddening of soil under favourable arid and semi-arid climatic conditions. The geochemistry data reveals that the sediments were derived from the felsic and mafic source rocks of granite, charnockite, hornblende biotite gneiss, khondalite, calcgranulite and aeolian sources from beach sand. The CIA results indicate a moderate to high weathering in the source area. Depositional geochemical analysis reveals finegrained clastic sediments that are chemically matured with high maturity index formed under the arid and semi-arid climate conditions.

\section{Declarations}

Conflict of interest The authors declare that they have no competing interests.

Open Access This article is licensed under a Creative Commons Attribution 4.0 International License, which permits use, sharing, adaptation, distribution and reproduction in any medium or format, as long as you give appropriate credit to the original author(s) and the source, provide a link to the Creative Commons licence, and indicate if changes were made. The images or other third party material in this article are included in the article's Creative Commons licence, unless indicated otherwise in a credit line to the material. If material is not included in the article's Creative Commons licence and your intended use is not permitted by statutory regulation or exceeds the permitted use, you will need to obtain permission directly from the copyright holder. To view a copy of this licence, visit http://creativecommons.org/licenses/by/4.0/.

\section{References}

Anaya-Gregorio A, Armstrong-Altrin JS, Machain-Castillo ML, MontielGarcía PC, Ramos-Vázquez MA (2018) Textural and geochemical characteristics of late Pleistocene to Holocene fine-grained deep-sea sediment cores (GM6 and GM7), recovered from southwestern Gulf of Mexico. J Palaeogeogr 7(3):253-271

Angusamy N, Loveson VJ, Rajamanickam GV (2004) Zircon and ilmenite from beach placers of southern coast of Tamil Nadu east coast of India. Ind J of Marine Sci 33:138-149

Angusamy N, Rajamanickam GV (2000) Distribution of heavy minerals along the beach from Mandapam to Kanyakumari. J Geol Soc India $56: 199-211$

Armstrong-Altrin JS (2020) Detrital zircon U-Pb geochronology and geochemistry of the Riachuelos and Palma Sola beach sediments, Veracruz State, Gulf of Mexico: a new insight on palaeoenvironment. J Palaeogeogr 9(28). https://doi.org/10.1186/ s42501-020-00075-9

Armstrong-Altrin JS, Lee Y, Verma SP, Ramasamy S (2004) Geochemistry of sandstones from the Upper Miocene
Kudankulam Formation, south India: implications for provenance weathering and tectonic setting. J Sediment Res 74(2):285-297

Armstrong-Altrin JS, Mayla A. Ramos-Vázquez, Nadia Y. Hermenegildo-Ruiz, Jayagopal Madhavaraju (2020) Microtexture and $\mathrm{U}-\mathrm{Pb}$ geochronology of detrital zircon grains in the Chachalacas beach, Veracruz State, Gulf of Mexico, Geologi J. 121. https://doi.org/10.1002/gj.3984.

Armstrong-Altrin JS, Botello AV, Villanueva SF, Soto LA (2019) Geochemistry of surface sediments from the northwestern Gulf of Mexico: implications for provenance and heavy metal contamination. Geologi Quarter 63(3):522-538. https://doi.org/10.7306/gq. 1484

Ashraf AS, Hoque A (2015) Heavy minerals assemblages at Cox's Bazar paleobeach core sediments, Cox's Bazar Bangladesh. IJETAE J 5(9)

Babu K (2017) Geochemical characteristics of sandstones from Cretaceous Garudamangalam area of Ariyalur, Tamilnadu, India: Implications of provenance and tectonic setting. J Earth Syst Sci 126(45). https://doi.org/10.1007/s12040-017-0821-3

Behera P (2003) Heavy minerals in beach sands of Gopalpur and Paradeep along Orissa coastline east coast of India. Ind J Marine Sci 32:172-174

Bijilal BS, Senthil Nathan D (2016) Geochemistry and clay mineralogy of weathering and soil profiles, Malappuram District, Northern Kerala, India: its implications on paleoclimate. J Geotech Eng 3(1):1-13

Condie CK, Noll PD, Conway CM (1992) Geochemical and detrital mode evidence for two sources of Early Proterozoic sedimentary rocks from the Tonto Basin Super group, central Arizona. Sediment Geol 77:51-76

Cox R, Lowe DR, Cullers RL (1995) The influence of sediment recycling and basement composition on evolution of mudrock chemistry in the southwestern United States. Geochi et Cosmoa Acta 59(14): 2919-2940. https://doi.org/10.1016/0016-7037(95)00185-9

Cronan DS (1972) The mid-Atlantic ridge near $45^{\circ} \mathrm{N}, \mathrm{XVII}: \mathrm{Al}, \mathrm{As}, \mathrm{Hg}$, and $\mathrm{Mn}$ in ferruginous sediments from the Median Valley. Can J Earth Sci 9(3):319-323. https://doi.org/10.1139/e72-025

Cullers R (1995) The controls on the major and trace element evolution of shales siltstones and sandstones of Ordovician to Tertiary age in the Wet Mountain region Colorado USA. Chem Geol 123:107-131

Cullers RL (2002) Implications of elemental concentrations for provenance, redox conditions, and metamorphic studies of shales and limestones near Pueblo, CO, USA [J]. Chem Geol 191(4):305-327

Cullers RL, Basu A, Suttner L (1988) Geochemical signature of provenance in sand-size material in soils and stream sediments near the Tobacco Root batholiths Montana USA. Chem Geol 70:335-348

Cullers RL, Podkovyrov VN (2000) Geochemistry of the Mesoproterozoic Lakhanda shales in southeastern Yakutia, Russia: Implications for mineralogical and provenance control, and recycling. Precambrian Res 104(1-2):77-93. https://doi.org/10. 1016/S0301-9268(00)00090-5

Dayal AM, Moorthy DSN (2006) Geochemistry of Pakhal shales. J Geol Soc India 67:770-776

Dhir R, Tandon SK, Sareen BK, Ramesh R, Rao TKG, Kailath AJ, Sharma N (2004) Calcretes in the Thar Desert: Genesis, chronology and palaeoenvironment Proc Indian. Acad Sci 113(3):473-515

Ergin MS, Keskin AU, Dogan YK, Kadioglu Z, Karakas (2007) Grain size and heavy mineral distribution as related to hinterland and environmental conditions for modern beach sediments from the Gulfs of Antalya and Finike, Eastern Mediterranean. Mar Geol 240:185196

Floyd PA, Winchester JA, Park RG (1989) Geochemistry and tectonic setting of Lewisian clastic meta sediments from the early Proterozoic Loch Maree Group of Gairloch, NW Scotland. Precambrian Res 45:203-214

Folk RL, Ward WC (1957) Brazos river bar: a study in the significance of grain size parameters. J Sediment Petrol 27:3-26 
Friedman GM (1961) Distinction between dune, beach and river sands from their textural characteristics. J Sediment Petrol 34:777-813

Hayashi S, Rubinfeld B, Souza B, Polakis P, Wieschaus E, Levine AJ (1997) Proc Natl Acad Sci U S A 94:242-247

Hendrik Falck, Stephen Day, Kelly L, Pierce, Scott Cairns, David Watson (2015) Geochemical, Mineralogical and Indicator Mineral Data for stream silt sediment, heavy mineral concentrates and waters, flat river area, NW Territories. (part of NTS 95E,105H and 1051)

Islam SMD, Rahman JJ (2009) Geochemical analysis of Miocene Siuma group sediments from the Meghna Gas field Bengal Basin Bangladesh Jahangirnagar University. J Dermatol Sci 32(1):29-46

Madhavaraju J, Rajendra SP, Lee YI (2020) Mineralogy and geochemistry of clastic sediments of the Terani Formation, Cauvery Basin, southern India: implications for paleoweathering, provenance and tectonic setting. Geosci J 24(2):1-17. https://doi.org/10.1007/ s12303-019-0047-2

Madhavaraju J, Ramasamy S (2002) Petrography and major element geochemistry of Late Maastrichtian-Early Palaeocene sediments of Tiruchirapalli Tamil Nadu: palaeoweathering and provenance implications. J Geol Soc India 59(2):133-142

Madhavaraju J, Lee YIL (2010) Influence of Deccan volcanism in the sedimentary rocks of Late Maastrichtian Danian age of Carvery basin South India: constraints from geochemistry. Curr Sci 98(4): 528-537

Mahamuda A, Emmanuel DS (2020) Geochemistry, grain size characterization and provenance of beach sands along the Central Coast of Ghana. Advan Rese in Chemi and Appli Scie 2(1):15-26

McLennan SM (1993) Weathering and global denudation. J Geol 101: 295-303

McLennan SM, Taylor SR (1991) Sedimentary rocks and crustal evolution tectonic setting and secular trends. J Geol 99:1-21

Meunier JD (1994) The composition and origin of vanadium-rich clay minerals in Colorado plateau Jurassic sandstones. Clays and Clay Min 42(4):391-401

Miao Y, Fang X, Song C, Yan X, Zhang P, Meng Q, Wang Y (2016) Late Cenozoic fire enhancement response to aridification in mid-latitude Asia: Evidence from microcharcoal records. Quat Sci Rev 139:5366. https://doi.org/10.1016/j.quascirev.2016.02.030

Milner HB (1962) Sedimentary petrology. George Allen and Unions Ltd, London, $\mathrm{p} 715$

Mir IA, Mir RA (2019) Geochemistry of surface sediments in parts of Bandipora-Ganderbal areas, Kashmir valley, western Himalaya: implications for provenance and weathering. J Earth Syst Sci:128-223. https://doi.org/10.1007/s12040-019-1248-9

Moiola RJ, Weiser D (1968) Textural parameters: an evaluation. J Sediment Petrol 38(1):45-53

Nagarajan R, Madhavaraju J, Nagendra R, Selvamony J, ArmstrongAltrin JM (2007) Geochemistry of Neo-Proterozoicshale's of the Rabanapalli Formation, Bhima Basin, Northern Karnataka, Southern India: implications for provenance and palaeo-redox conditions. Revi Mexi De Ciens Geol 24:150-160

Nesbitt HW, Young GM (1982) Early Proterozoic climates and plate motions inferred from major element chemistry of lutites. Nature 299:715-717

Perumal V (2017) Petrography and geochemistry of calcrete deposit in and around Sathankulam Region, Southern Tamilnadu, India. Ph.D. In: Thesis published at Manonmaniam Sundaranar University. Tirunelveli, Tamilnadu http://hdl.handle.net/10603/207324

Perumal V, Udayanapillai AV (2019) Micromorphology and major element geochemistry of calcretes in the Thoppukulam mine section, Sathankulam region, Southern Tamil Nadu, India: implications on depositional environment. Arab J Geosci 12(385):1-12. https://doi. org/10.1007/s12517-019-4544-4

Perumal V, Udayanapillai AV (2020) Calcrete profiles in Puthukulam quarry section, Sathankulam region, Southern Tamilnadu, India: implications on palaeoclimate significance. J Sediment Environ 5: 493-503. https://doi.org/10.1007/s43217-020-00029-0

Perumal V, Udayanapillai AV (2015) Petro-mineralogy and major elements geochemistry of Regolith profile of calcrete deposits at Pandalgudi, Viruthunagar District, Tamilnadu, India. Int Rese J Earth Sci 3(9):1-7 https ://www.resea rchga te.net/publi catio n/ 318440925

Pettijohn FJ (1975) Sedimentary rocks 2 ed. Harper and Row, New York 628.

Poppe LJ, Eliason AH (2008) A Visual Basic program to plot sediment grain-size data on ternary diagrams. Comp and Geo Sci 34:561-565

Ramaswamy V, Rao PS (2006) Grain Size Analysis of Sediments from the Northern Andaman Sea: Comparison of Laser Diffraction and Sieve-Pipette Techniques. J Coast Res 22(4):1000-1009. https://doi. org/10.2112/04-0162.1

Ramos-Vázquez MA, Armstrong-Altrin JS (2019) Sediment chemistry and detrital zircon record in the Bosque and Paseo del Mar coastal areas from the southwestern Gulf of Mexico. Marine and Petroleum Geo 110(650-675). https://doi.org/10.1016/j.marpetgeo.2019.07. 0321

Ramos-Vazquez MA, Armstrong-Altrin JS (2020) Provenance and palaeoenvironmental significance of microtextures in quartz and zircon grains from the Paseo del Mar and Bosque beaches, Gulf of Mexico. J Earth Syst Sci 129(1):1-26. https://doi.org/10.1007/ s12040-020-01491-0

Roaidest E (1978) Mineralogical and chemical changes during weathering, transportation and sedimentation in different environments with particular references to the distribution of Yttrium and lanthanide elements. In: Ph.D. Thesis, Geol Inst Univ of Oslo Norway

Sachinath Mitra (1989) Fundamental of optical spectroscopic and X-ray. Mineralogy Wiley. http://www.worldcat.org/oclc/17300449.

Shaheen SM, Alessi DS, Tack FMG, Ok YS, Kim KH, Gustafsson JP, Rinklebe J (2019) Redox chemistry of vanadium in soils and sediments: interactions with colloidal materials, mobilization, speciation, and relevant environmental implication-a review. Adv Colloid Interf Sci. https://doi.org/10.1016/j.cis.2019.01.002

Shehata MG, Abdou AA (2008) Geochemical study of the shale of Gebel El - dist Member Bahariya Oasis Western Desert Egypt. Aust J BAS 2(2):243-251

Songjong Kwaka, Yooa J-C, Moonb DH, Baeka K (2018) Role of clay minerals on reduction of $\mathrm{Cr}(\mathrm{VI})$. Geoderma 312:1-5

Suttner LJ, Dutta PK (1986) Alluvial sandstone composition and palaeoclimate framework mineralogy. J Sediment Petrol 56(3): 329-345

Taylor SR, McLennan SM (1985) The continental crust: its composition and evolution Blackwell Scientific Publi Oxford 312.

Thiruvikramji KP, Joseph S, Anirudhan S (2008) Teri's of Southern Tamilnadu: a Saga of Holocene climate change. Memoir of Geol Soc India 74:351-359

Udayanapillai AV, Ganesamoorthy P (2013) Mineralogical and geochemistry of red and black sediments Thoothukudi District Tamilnadu India. Geol J soc of Sri Lanka 15:47-56

Udayanapillai AV, Perumal V, Armstrong-Altrin JS (2020) Provenance weathering, tectonic setting and palaeo-oxygenation condition of the Cretaceous Calcareous Grey Shale (CGS) from the Kallakudi Dalmia Limestone Quarry No: II Uttatur group Trichinopoly Tamilnadu India. Himal Geol 41(1):11-20

Udayanapillai AV, Perumal V, Armstrong-Altrin JS, Satyanarayanan M (2016) Micromorphology, Geochemistry and Spatial evaluation of Calcrete deposits in and around Sathankulam, Tuticorin District, Tamilnadu, India. J Geosci Resea 1(2):111-118

Udayanapillai AV, Perumal V, Thirugnasambandam R, Venkataraman P, Thangavel M (2015) Study of micro-morphology, major element geochemistry and palaeoclimatic implications of calcrete deposits 
at Salukkuvarpatti Village, Near Pandalgudi, Viruthunagar District, Tamilnadu, India. Appli. Geochemistry 17(4):421-431

Verma RK, Prasad SN (1974) Paleomagnetic study and chemistry of newer dolerites from Singhbhum Bihar, India. Canadian J Earth Sci 11(8):1043-1054. https://doi.org/10.1139/e74-103

Vetha Roy D, Chandrasekar N (2007) Minor and Trace elements in Tambraparani Estuary, India. Ecol Environ Conserv 13(4):761-767

Visher GS (1969) Grain size distributions and depositional processes. Journal of Sedimentary. Petrology 39:1074-1106
Willis KM, Stern RJ, Claur N (1988) Age and geochemistry of Late Precambrian sediments of the Hammamat series from the Northeastern desert of Egypt. Precambrian Res 42:173-187

Zaid SM (2015) Geochemistry of sandstones from the Pliocene Gabir Formation, north Marsa Alam, Red Sea, Egypt: implication for provenance, weathering and tectonic setting. J Afr Earth Sci 102: 1-17. https://doi.org/10.1016/j.jafrearsci.2014.10.016 